\title{
Genetic Diversity of Toxoplasma Gondii by Serological and Molecular Analyzes in Different Sheep and Goat Tissues in Northeastern Iran
}

Nima Firouzeh

Kerman University of Medical Sciences

Hamid Foroughiborj

Kerman University of Medical Sciences

Naser ziaali

Kerman University of Medical Sciences

Amir Tavakoli Kareshk ( $\sim$ atk9388@gmail.com )

Birjand University of Medical Sciences

\section{Research}

Keywords: Toxoplasma gondii, Sheep \& Goat, MAT, PCR-RFLP, Genotyping

Posted Date: September 13th, 2021

DOI: https://doi.org/10.21203/rs.3.rs-853244/v1

License: (c) (i) This work is licensed under a Creative Commons Attribution 4.0 International License. Read Full License 


\section{Abstract}

Background: Toxoplasmosis, a parasitic disease caused by compilation protozoan agent Toxoplasma gondithat led to significant financial and quality-adjusted life-year losses. Consumption of undercooked or raw meat has been regarded as a major route of transmission. The present study was conducted to determine the seroposevitity rate of T.gondii in sheep and goats by serological and molecular tests and also genotyping of obtained isolatesin northeast of Iran.

Methods: Blood and tissue samples (diaphragm, heart) of 296 animals (including 168 sheep and 128 goats) were collected from slaughterhouse in Quechan city from august 2016 to April 2017. Serum samples examined by the Modified agglutination test (MAT) and the Nested-PCR method performed to amplify the fragment of the B1 gene to detect parasite DNA on diaphragm and heart tissues of seropositive animals. PCR-RFLP method of GRA6 gene was used to determine the genotype of $T$. gondii. Also, sequencing analysis was performed to evaluate the Toxoplasma type strains.

Results: Serum positive for MAT results were found in $27.4 \%$ (46/168) of Sheep and23.4\% (30/128) of goats. Positive Nested-PCR of B1 gene results in diaphragm and heart tissues of sheep and goats was $47.8 \%(22 / 46)$ and $26.1 \%(12 / 46), 40 \%(12 / 30)$ and 23.3\% (7/30), respectively. Nested-PCR of GRA6 gene results were positive in 10 samples (7 sheep and 3 goats) that RFLP technique results with using Msel enzyme revealed genotype I. Sequencing and Phylogenetic analysis revealed DNA of all samples were closely related to Toxoplasma type I.

Conclusions: Concerning to highseropositivityrate of toxoplasmosis in studied region, undertaking an appropriate preventive program for reducing the prevalence of $T$. gondii infection by raw or undercooked meat consumption of livestock recommended. Our study supports the notion that consumption of raw and undercooked meat of these animals can be a probable source of human toxoplasmosis.

\section{Background}

Toxoplasma gondii (T.gondii) is an obligate intracellular protozoan, which is widely prevalent in humans and other animals[1,2].Felines particularly cats are definitive hosts in the life cycle of T.gondii and excrete millions of resistant oocysts after primary infection into the environment. Almost all warm-blooded plays a role in transmission cycle as intermediate hosts such as sheep, goat, cattle, pigs and camels or aberrant hosts as humans[3]. Even though most cases of human infection are asymptomatic or mild clinical symptoms, the parasite can cause severe complications such as encephalitis in congenitally infected children and immunocompromised individuals[4,5].Reactivations of latent infection in immunocompromised individuals can cause fatal toxoplasmicencephalitis, pneumonitis and myocarditis. Acquired infections during pregnancy associated with severe damage to the fetusincluding stillbirths or abortions. Humans usually infected viaconsumption of undercooked meat containing tissue cysts or cyst contaminated water. Oral uptake of oocysts in soil, contact to cat feces, organ transplantation or blood transfusion, transplacental transmission and accidental inoculation of 
tachyzoites consider as other routes of getting infected to toxoplasmosis [6,7].T .gondii is broadly spread among farm animals and humans. Overall assessed frequency is reportedwith variable seroprevalence rates of $75 \%$ in dogs, $11-36 \%$ in pigs, $11-61 \%$ in goats, less than $10 \%$ in cows, $35-73 \%$ in cats, and 35 $73 \%$ in humans[8,9]. Whereas this value in Iran and humans has been reported 29 to $55 \%$ [10].In KhorasanRazavi province, the seroprevalence rate of toxoplasmosis in sheep was found $15.5 \%$. Also, another recent study in Sabzavar city in KhorasanRazavi province revealed that $60 \%$ of sheep, $52.5 \%$ of goats and $65 \%$ of camels were infected by T.gondii.[11,12].According to the published data related to the census of animal husbandry in Iran,(https://www.amar.org.ir/), KhorasanRazavi province is the most important provinces in livestock breeding, and Quchan city is the animal husbandry hub of this province.So, it is essential to evaluate the prevalence of Toxoplasma gondii in livestock as humans food. Lack of accurate and comprehensive data concerning to livestock prevalence of toxoplasmosis in this area is the main obstacle to control and design preventive plan. So, the present study was conducted to survey the frequency of T.gondii in livestock meat (sheep and goats) by using (MAT) test and compare with polymerase chain reaction (PCR) methods as well as to determine genetically diversity infecting strains of T. gondii.

\section{Ethics}

Te study has been approved by the Ethics Committee of the kerman university of medical sciences in iran(reference number: 94/389).

\section{Methods}

\section{Study area}

This Cross-Sectional study that was conducted in Quchan city in KhorasanRazavi province in northeastern Iran. It has an area of about 523400 hectares and a population of over 180,000 peoples. The city is located in a mountainous area, elevation 1149 meters above sea level and has cold winters and mild summers. Its rainfall is $200-150 \mathrm{~mm} /$ year and lies between $37.11^{\circ}$ latitude and $58.51^{\circ} \mathrm{E}$ longitude. (Available athttps://www.worldatlas.com/as/ir/30/where-is-quchan.html, https://en.wikipedia.org/wiki/Quchan\#Geography). Figure.1 shows ArcGIS geographic location of Iran and Quechan.

\section{Sample collection}

Based on statistical advice and previous studies, a total of 296 animals including 168 sheep and 128 goats were sampled from the slaughterhouse in Quechan city for this study. This descriptive crosssectional study was implemented during the period from August 2016 to April 2017 and samples were collected in four stages in the spring, summer, autumn and winter seasons. According to the seasonal pattern, 65 68, 104 and samples were collected in spring; summer, autumn in winter respectively. Livestock was numbered, randomly selected, whereastheir blood samples(jugular vein) were obtained from a numbered livestock. At the same time, age and gender were also recorded. According to the 
number of each livestock, about $10 \mathrm{gr}$ of heart and diaphragm tissues were obtained from the same livestock. Totally, we had from each livestock a blood sample, a heart sample and a diaphragm sample. Blood samples were centrifugedin withoutanticoagulant tubes at $8000 \mathrm{rpm}$ for 5-10 minutes and sera were transferred to $1.5 \mathrm{ml}$ micro-tubes. All sampling was carried out in compliance with ethical requirements. Till to performing serological and molecular tests, all sera and tissue samples were stored at $-20{ }^{\circ} \mathrm{C}$ until.

\section{Serological examination}

Sera of sheep and goats were examined for anti-toxoplasmagondii antibodies by the modified agglutination test (MAT) (Toxo screen DA, bi-omerieux®, France) as described by Dubey and Desmonts[13].Serumsamples (sheep and goats) were diluted from 1:20 to 1:640. Accordingly to the manufacturer's instructions, antibodies titers of 1:20 or higher were considered positive.

\section{DNA extraction}

All positive samples of MAT test were investigated by PCR assay on the heart and diaphragm of the same animals. For this purpose, $20 \mathrm{mg}$ of tissues were transferred into a sterile plate and crushed. This work continued until the sample was completely homogeneous. Then, homogenized tissue is transferred into a $1.5 \mathrm{ml}$ microcentrifuge tube and subsequent stages of DNA extraction were performed using (Gene All, Exgene,Cell SV mini, Korea) kit and according to the manufacture`s instruction.

\section{Nested-PCR for B1 gene}

The Nested-PCR assays were accomplished based on two repeated genomic targets, B1, to detect T. gondii DNA in contaminated tissues. B1 Gene is 35 times reported and has high sensitivity and specificity of PCR in the determination of the contamination of clinical samples with T.gondii[13] .Two PCR primer pairs of the B1 gene, S1 (5'-CGACAGAAAGGGAGCAAGAG-3') and AS1 (5'-ACGCTGTGTCTCCTCTAGGC-3 '), S2 (5'-TCTTCCCAGACGTGGATTTC-3') and AS2 (5'-CTCGACAATACGCTGCTTGA-3'), eventually amplifying a $531 \mathrm{bp}$ fragment were used. The first amplification was carried out in $20 \mu \mathrm{l}$ of reaction mixture containing $1 \mu \mathrm{l}$ of each primer (S1 and AS1), 10 $\mu$ l Master mix (Ampliqon Company, Denmark), 2 $\mu l$ extracted DNA from heart or diaphragm samples and $6 \mu$ l Distilled water sterilized. The first PCR was performed in a thermocycler (Flex Cycler) for initial denaturation at $94 \mathrm{C}$ for $3 \mathrm{~min}$, this step was followed by 35 cycles of denaturation at $94 \mathrm{C}$ for $30 \mathrm{~s}$, annealing at $60 \mathrm{C}$ for $30 \mathrm{~s}$, extension at $72 \mathrm{C}$ for $2 \mathrm{~min}$ and a final extension step at $30 \mathrm{C}$ for $1 \mathrm{~min}$. The second amplification was performed in $20 \mu \mathrm{l}$ reaction mixture. The first PCR product was diluted with a ratio of 1:40 to distilled water, and then used as a template. Twenty $\mu \mathrm{l}$ reaction mixture was containing $1 \mu \mathrm{l}$ of each primer (S2 and AS2), $8 \mu \mathrm{l}$ Master mix (Ampliqon Company, Denmark), $1 \mu$ l of our new template and $9 \mu$ distilled water sterilized. The second PCR was performed in 30 cycles. The PCR products were electrophoresed in a 1.5\% Agarosegel in tris-borate-EDTA 0.5X (TBE 0.5X) buffer and stained with Ethidium bromide. Additionally,negative and positive control respectively include sterile waterand extracted DNA from $T$. gondiitachyzoites $\mathrm{RH}$-strain was used in this method. 


\section{Nested PCR for GRA6 gene}

The positive samples of Nested-PCR of B1 gene included in analyzing by Nested-PCR of GRA6 gene. GRA6, ahighly polymorphicgene is repeated in the genome of the T. gondii. This gene is suited to distinguish between three typesI, II and III from each other, especially type III which is close to type I. Two PCR primer pairs of the GRA6 gene, GRA6FO (5'GGCAAACAAAACGAAGTG-3') and GRA6RO (5'CGACTACAAGACATAGAGTG-3') used in first amplification, and GRA6R (5'-GTAGCGTGCTTGTTGGCGAC$3^{\prime}$ ) and GRA6 (5'TACAAGACATAGAGTGCCCC-3') used in second amplification. The first amplification was carried out in $25 \mu \mathrm{l}$ of reaction mixture containing $1 \mu \mathrm{l}$ of each primer (GRA6FO and GRA6RO), 8 $\mu$ l Master mix (Ampliqon Company, Denmark), $5 \mu$ l extracted DNA of heart or diaphragm samples and $10 \mu$ Distilled water sterilized. The first PCR was performed in a thermocycler (Flex Cycler) for initial denaturation at 94 $\mathrm{C}$ for $5 \mathrm{~min}$, this step was followed by 35 cycles of denaturation at $94 \mathrm{C}$ for $30 \mathrm{~s}$, annealing at $54 \mathrm{C}$ for 60 $\mathrm{s}$, extension at $72 \mathrm{C}$ for $90 \mathrm{~s}$ and a final extension step at $72 \mathrm{C}$ for $7 \mathrm{~min}[14]$.The second amplification was performed in $25 \mu \mathrm{l}$ reaction mixture. The first PCR product used as a template while diluted with a ratio of 1:10 to distilled water.Twenty-five microlitresreaction mixture was containing $1 \mu$ l of each primer (GRA6R and GRA6), $8 \mu$ l Master mix, $1 \mu$ l of our new template and $14 \mu$ l Distilled water sterilized. The second PCR was performed at the annealing temperature of $60 \mathrm{C}$ for the $60 \mathrm{~s}[15]$. The PCR products were electrophoresed in a 1.5\%agarosegel in tris-borate-EDTA 0.5X (TBE 0.5X) buffer and stained with ethidium bromide.To differentiate the three types (I, II, III) of T.gondii,all positive samples of Nested PCR for GRA6 gene were used to performing PCR-RFLP technique.

\section{PCR-RFLP}

The GRA6 gene amplified product was digested with Msel with Mse/restriction endonuclease $(10 \mathrm{U} / \mu \mathrm{l}$, 300 units), (Fermentas, Thermo Scientific, USA). As described by the manufacturer, $15 \mathrm{ml}$ of PCRproduct was exposedto $1.5 \mathrm{U}$ of Mselen-zyme and $2 \mathrm{U}$ buffer $\mathrm{R}$ and incubated at $65^{\circ} \mathrm{C}$ for $4 \mathrm{~h}$. The restriction fragments were separated by electrophoresis in $2 \%$ agarose gel followed by staining with ethidium bromide and visualization under UV. The cut position of Mse/in GRA6 genes of types I, II, and III was 168 bp and 712 bp, 71 bp and 694 bp, and 71 bp, 168 bp, and 712 bp, respectively.

\section{Sequencing}

The GRA6 gene amplified product (with suitable quality in PCR-RFLP) sent to Macrogen company (South Korea) to sequence analyzing and also to obtain more accurate results from the genotype of the $T$. gondii(I, II, III). Results were aligned with BioEdit and sequence Scanner program and compared to the following sequence data available from GeneBank: AJ635332, AF239283, AF239292 and AF239284.The maximum-likelihood analysis was employed to estimated phylogenetic relationshipsamong genotypes. Additionally, Mega 6 andBioEdit software were used to construct thephylogeny tree to compare our collected isolates against types submitted in Genebank as well as to demonstrate homology of obtained sequences respectively.

\section{Statistical Analysis}


Differences in T. gondii prevalence with variables such as season, sex and age and calculate the prevalence rate was analyzed using Pearson Chi-square test and crosstab. Statistical analysis was performed using SPSS version 23 software for Windows. The $p$-values less than 0.05 were considered as statistically significant.

\section{Results}

\section{Serological, molecular and risk factor}

In the present study, T.gondii antibodies (MAT titers $\geq 1: 20$ ) were found in $46(27.4 \%)$ of 168 sheep and $30(23.4 \%)$ of 128 goats (Table1). The samples assayed at dilution from 1:20 to 1:640 (Table2). Also, positive results were categorized at dilution of $\geq 1: 20$ based on the seasons, sex and age (Tables 3 and 4).

Table 1

Toxoplasma infection in sheep and goats by MAT method at $\geq 1: 20$ dilution

\begin{tabular}{|c|c|c|c|c|}
\hline \multirow[t]{2}{*}{ animal } & \multicolumn{2}{|l|}{ MAT } & \multirow[t]{2}{*}{ total } & \multirow[t]{2}{*}{ Percent (\%) } \\
\hline & positive & negative & & \\
\hline sheep & 46 & 122 & 168 & 27.4 \\
\hline goats & 30 & 98 & 128 & 23.4 \\
\hline
\end{tabular}

Table 2

Toxoplasma infection in sheep and goats by MAT at 1:20 to 1:640

dilution

\begin{tabular}{|llll|}
\hline & & Sheep & Goats \\
\hline MAT & $1: 20$ & 18 & 8 \\
\cline { 2 - 4 } & $1: 40$ & 13 & 10 \\
& $1: 80$ & 9 & 8 \\
& $1: 160$ & 4 & 3 \\
\hline $1: 320$ & 1 & - \\
\hline Total & & 46 & 30 \\
\hline
\end{tabular}


Table 3

Toxoplasma infection in sheep and goats by MAT method at $\geq 1: 20$ dilution based on seasons and sex

\begin{tabular}{|clllllll|}
\hline & & \multicolumn{3}{c}{ Season } & & \multicolumn{3}{c|}{ Sex } \\
\cline { 3 - 8 } & & Spring & Summer & Autumn & Winter & Male & Female \\
\hline \multirow{5}{*}{ Sheep } & Positive & 5 & 8 & 17 & 16 & 20 & 26 \\
\cline { 2 - 8 } & Negative & 40 & 32 & 38 & 12 & 88 & 34 \\
\cline { 2 - 8 } & Total & 45 & 40 & 55 & 28 & 108 & 60 \\
\cline { 2 - 8 } & Seroprevalence (\%) & 11.1 & 20 & 30.9 & 57.1 & 18.5 & 43.3 \\
\cline { 2 - 8 } & Positive & 2 & 5 & 13 & 10 & 15 & 15 \\
\cline { 2 - 8 } & Negative & 18 & 23 & 36 & 21 & 65 & 33 \\
\cline { 2 - 8 } & Total & 20 & 28 & 49 & 31 & 80 & 48 \\
\cline { 2 - 8 } & Seroprevalence (\%) & 10 & 17.9 & 26.5 & 32.3 & 18.8 & 31.3 \\
\cline { 2 - 7 } & & & & & & & \\
\hline
\end{tabular}

Table 4

Toxoplasma infection in sheep andgoats by MAT method at $\geq 1: 20$ dilution based on ages

\begin{tabular}{|c|c|c|c|c|c|c|}
\hline Age & Sheep & & & Goat & & \\
\hline MAT & & Percent (\%) & MAT & & Percent (\%) & \\
\hline Positive & Negative & & Positive & Negative & & \\
\hline «1 & 1 & 24 & 4 & 1 & 32 & 3 \\
\hline $1-3$ & 15 & 59 & 20.3 & 13 & 44 & 22.8 \\
\hline $3-5$ & 21 & 32 & 39.6 & 8 & 13 & 38.1 \\
\hline$>5$ & 9 & 7 & 56.3 & 8 & 9 & 47.1 \\
\hline Total & 46 & 122 & 27.4 & 30 & 98 & 23.4 \\
\hline
\end{tabular}

The comparison of collected Toxoplasmaseropositivity data and different seasonal patterns in sheep indicate significant differences (P-value $<0.05)$, while there was no significant difference in goat (P-value $>0.05)$.

Our analyzed data showed a statistically significant difference between age associations and Toxoplasmaseropositivity in both sheep and goat $(P$-value $<0.05)$.

Also, the results of statistical analysis showed a significant difference between sex associations with seropositive in sheep ( $P$-value $<0.05)$; whereas there was no significant difference in goat $(P$-value $>0.05)$. 
The univariate analysis for sheep showed a significant difference between Toxoplasma seropositivityand the sex; however, the same difference about goat was not significant.

\section{Table 5}

and Fig. 2 depict the results of Nested-PCR for B1 gene on heart and diaphragm tissue samples of the same animals with previously positive MAT reports.

\begin{tabular}{|c|c|c|c|c|c|c|c|}
\hline Animal & No. & Tissue & $\begin{array}{l}\text { No. } \\
\text { tissue }\end{array}$ & $\begin{array}{l}\text { No. positive } \\
\text { samples at } \\
\text { Nested-PCR } \\
\text { with using B1 } \\
\text { gene }\end{array}$ & $\begin{array}{l}\text { Percent } \\
(\%) \\
\text { infection } \\
\text { in each } \\
\text { tissue }\end{array}$ & $\begin{array}{l}\text { No. infection in } \\
\text { each animal at } \\
\text { Nested-PCR } \\
\text { with using B1 } \\
\text { gene }\end{array}$ & $\begin{array}{l}\text { Percent(\%), } \\
\text { in each } \\
\text { animal }\end{array}$ \\
\hline \multirow[t]{2}{*}{ Sheep } & \multirow[t]{2}{*}{46} & Diaphragm & 46 & 22 & 47.8 & \multirow[t]{2}{*}{27} & \multirow[t]{2}{*}{58.7} \\
\hline & & Heart & 46 & 12 & 26.1 & & \\
\hline \multirow[t]{2}{*}{ Goats } & \multirow[t]{2}{*}{30} & Diaphragm & 30 & 12 & 40 & \multirow[t]{2}{*}{16} & \multirow[t]{2}{*}{53.3} \\
\hline & & Heart & 30 & 7 & 23.3 & & \\
\hline
\end{tabular}

Table 5. Results of Nested-PCR forB1 gene on the heart and diaphragm tissues that their MAT results at $\geq 1: 20$ dilution were positive.

*It is worth mentioning, in 2 male sheep, 5 female sheep and 3 female goats, simultaneous infection of heart and diaphragm were observed.

The analyzed data indicatea significant difference between dilutions of serumand positive results of Nested-PCR for B1 gene in sheep and goat ( $P$-value < 0.05).Moreover, 30 samples with negative MAT results were randomly selected and examined under the Nested-PCR B1 gene on heart and diaphragm tissues that all samples were negated.Table 6 and Figure. 3 demonstrated the related results about Nested-PCR for GRA6 gene that was performed on positive samples of Nested-PCR of B1 gene. Figure 4 exhibits the results of. PCR-RFLP technique (to determine the genotypes of T.gondi) that carry out on positive samples of Nested-PCR for GRA6 gene.

Table 6

Nested-PCR results for GRA6 gene on the positive samples of Nested-PCR of B1 gene

\begin{tabular}{|lllll|}
\hline Animal & No. & Tissue & $\begin{array}{l}\text { No. } \\
\text { tissue }\end{array}$ & $\begin{array}{l}\text { No. positive samples at Nested-PCR with using GRA6 } \\
\text { gene }\end{array}$ \\
\hline Sheep & 27 & Diaphragm & 22 & 6 \\
\cline { 2 - 5 } & & Heart & 12 & 1 \\
\hline \multirow{2}{*}{ Goats } & 16 & Diaphragm & 12 & 3 \\
\cline { 2 - 5 } & & Heart & 7 & - \\
\hline
\end{tabular}

Additionally, our analyzed results represent a significant difference between dilutions of serums and positive results of Nested-PCR for GRA6 gene in sheep and goat (P-value $<0.05$ ). 


\section{Sequencing And Phylogenetic Analysis}

As shown in Fig. 5 phylogenetic analysis of 10 sequenced products confirmed that all isolates belonged to type 1 with high similarity in sister clade and their sequences are available in Genbank with accession numbers:MG976038 to MG976047. Homology of identified sequence compared with gene-bank sequences (Fig. 6).

\section{Discussion}

This study was conducted to determinetheseropositivity and molecular detection of T.gondii in sheep and goatin northeastern of Iran.Goats and sheep are the most important livestock in societies that deal with agriculture and animal husbandry such as Iran and their products consider as main food sources for humans. Despite some progress in the diagnosis and treatment of toxoplasmosis, the disease remains a major zoonosis in many parts of the world, causing significant public health and economic losses. Based on a previous comprehensive study, maximum and minimum worldwide seropositivity of sheep was reported $4.4 \%$ (in China), 99.2\% (in France)and the same result for goats was founded in ranged from 3.7 to $81 \%$ [16]; Whereas these value in Iran for sheep and goats were recorded between 13-35\% and 13$30 \%$ respectively[17]. The MAT, a standard method, has unique properties such as high sensitivity (more than $82.9 \%$ ) and specificity (more than $90.29 \%$ ) was selected to determine seropositivity of Toxoplasma in our research[18].Our study revealed that the seropositivity of Toxoplasma in sheep and goats was $27.4 \%$ and $23.4 \%$, respectively. These values are in agreement with finding in various area of Iran including $18.8 \%$ and $29.5 \%$ in Fars province, $24.7 \%$ and $15.8 \%$ in Kerman province for sheep and goats respectively; as well as $21.1 \%$ of sheep in Urmia[19-21].Relative high seropositivity rate was recorded in Mazandaran province of Iran,where 588 and 400 serum samples of sheep and goats examined and seropositivity was found $35 \%$ and $30 \%$ for sheep and goats respectively; Whereas low seropositivity (3.1 $\%$ of sheep) was reported in Western of Iran[22,23].Comparison of our findings with those of previous studies fromother parts of the world revealed more or fewersimilarities/differences. For instance, in two studies of China serologic evidence of infection was found in $12.71 \%$ of sheep and $20.3 \%$ of goats[ $24,25]$.Additionally, in an effort by Dubey et al. to estimate seropositivity of 234 goats in USA, it was shown $53.4 \%$ of goats were positive[13].It is well known that discrepancies in overall seropositivity results for toxoplasmosis in animals may be attributed to kind of used serological test, sample size, ecological status, management and hygienic standards and other factors.Generally, MAT was selected as a first choice method to evaluate seropositivity of Toxoplasma in animals, whereas in several studies molecular methods were used to determine the rate of toxoplasmosis in animals [19].In this regard, our molecular results via B1 gene shows $58.7 \%$ and $53.3 \%$ of studied sheep and goats were infected with T.gondii and this is in agreement with the finding of $56.66 \%$ and $44.16 \%$ for sheep and goats in Kerman province respectively [26].In line with our finding in Iran,Aziziet al.shows that $38 \%$ of studied sheep in ChaharmahalvaBakhtiary province were infected with Toxoplasma; As well assimilar results were taken in the Fars province in the investigation of 56 sheep and 22 goats tissue samples witch total molecular prevalence of Toxoplasma was $33.3 \%$ [19,27]. Our molecular prevalence data are comparable with other worldwide reports; for example in Tunisia, it has been proved that $33.3 \%$ and $32.5 \%$ of B1 gene Nested 
PCR tests were positive for ewes and goats respectively [28].Routinely, genotyping as a crucial determinant for pathogenesis and virulence of Toxoplasma was performed in recent studies. It has been reported that there is a correlation between of T.gondii genotype and clinical symptoms and pathogenesis profile of parasite[29,30]. Besides, it is verified that genotype I known as acutely virulent; whereasgenotype II and III are significantly less virulent that can establish latent toxoplasmosis [31].Due to specific polymorphisms of GRA6 marker, it was selected in our study to genotyping of isolated T.gondii and at the next step PCR-RFLP test viaMsel endonuclease was performed to discriminate between types I, II, and III[32].Nested-PCR of GRA6 gene for 10 tissue samples (7 sheep and 3 goats) was positive and RFLP technique approved all of them cluster into genotype $\mathrm{l}$. These results are in agreement with two previous surveys of different parts of Iran $[33,34]$.It is proven that predominant genotype in animal especially ruminants in Iran is genotype II; Whereas prior European investigation demonstrated the most predominant genotype belongs to type III [35].In our study, variables analysis in sheep and goats showed that infection rate of toxoplasmosis increased with age. This age-related variation can be due to the fact that older animals have been exposed to risk factors for a longer time. Also, infection rate in sheep is higher in dry than wet seasons. Likewise, female sheep has more chance to acquire Toxoplasmosis than male. Infection occurs more often in the wet season, and since IgG antibodies can persist a long time, so the high infection in dry season might be due to the carry-over effect from preceding wet season infections. Some studies have analyzed age, sex and season variables and relationship with infection rates to T.gondii.In a study conducted by Tegegne et al, in Ethiopia,their Analysis of age and sex variables showed that seropositivity was higher in adults than younger animals and also higher in females than males [8].The finding related to influence of age and seasons on seropositivityof studied animals was verified by parallel research which conducted in various part of the world [36,37].Collectively, discovering series factors such as seropositivity of toxoplasmosis, the biological properties of parasite and other risk factors in sheep and goats as main human foods are tied to establish efficient prevention and control health programs against toxoplasmosis.

\section{Conclusion}

This study can serve as a road map and useful information source toclarifythe quantitative riskassessment of toxoplasmosis in humans as a foodborne disease.Presence of T.gondii DNA in the tissues of sheep and goats from northeastern Iran implicating that the consumption of meat might pose the risk of human infection.It is approved that MAT has more performance thanmolecular (PCR) methods to diagnosis of toxoplasmosis in sheep and goats.So combination usage of MAT and molecular methods is recommended. This investigation depicts new perspectives about the genotyping map of T.gondii which is an indispensable factorfor evaluation of meaningful control and prevention strategies.

\section{Declarations}

\section{Acknowledgements}

We are thankful to Kerman University Of Medical Sciences for support this project. 


\section{Authors' contributions}

ATK and NZ, designed the study. HF collected the data and contributed to the manuscript. ATK and NF wrote the manuscript and was involved in the interpretation of the data, and the coordinator researcher. $\mathrm{HF}$ and NZ carried out the statisticalanalyses of the data. All authors read and proved the final manuscript. The author(s) read and approved the final manuscript.

\section{Funding}

The present study was funded by the Kerman University Of Medical Sciences (Project No. 94/389).

\section{Availability of data and materials}

Data supporting the conclusions of this article are provided within the article. Raw data are available from the corresponding author upon request.

\section{Declarations}

\section{Ethics approval and consent to participate}

The process of tissue collections from animals was approved by the Ethics Committee of kerman university of medical Science. (Project No. 94/389).

\section{Consent for publication}

Not applicable.

\section{Competing interests}

The authors declare that they have no competing interests.

\section{Author details}

${ }^{1}$ Department of Medical Parasitology and Mycology, School of Medicine, Kerman University of Medical Sciences. ${ }^{2}$ Infectious Disease Research Center, Birjand University of Medical Sciences, Birjand, Iran.

${ }^{3}$ Student Research Committee, Birjand University of Medical Sciences, Birjand, Iran.

\section{References}

1. Dubey JP. Toxoplasmosis in pigs-the last 20 years. Vet Parasitol. 2009;164(2-4):89-103.

2. Shojaee S, Firouzeh N, Keshavarz H, AZAMI SJ-P, Salimi M, Mohebali M. Nanosilver Colloid Inhibits Toxoplasma gondii Tachyzoites and Bradyzoites in Vitro. Iran J Parasitol. 2019;14(3):362.

3. Verhelst D, De Craeye S, Vanrobaeys M, Czaplicki G, Dorny P, Cox E. Seroprevalence of Toxoplasma gondii in domestic sheep in Belgium. Vet Parasitol. 2014;205(1-2):57-61. 
4. Opsteegh M, Teunis P, Züchner L, Koets A, Langelaar M, van der Giessen J. Low predictive value of seroprevalence of Toxoplasma gondii in cattle for detection of parasite DNA. Int J Parasitol. 2011;41(3-4):343-54.

5. Teimouri A, Azami SJ, Keshavarz H, Esmaeili F, Alimi R, Mavi SA, et al. Anti-toxoplasma activity of various molecular weights and concentrations of chitosan nanoparticles on tachyzoites of RH strain. Int J Nanomedicine. 2018;13:1341-51.

6. Zarean M, Shafiei R, Gholami M, Fata A, Balaghaleh MR, Karimi A, et al. Seroprevalence of antitoxoplasma Gondii antibodies in healthy voluntary blood Donors from Mashhad City, Iran. Arch Iran Med. 2017;20(7):441.

7. Tavakoli Tavakoli A, Keyhani A, Asadi A, Zia-Ali N, Mahmoudvand H, Mohammadi AR. Seroprevalence of Toxoplasma gondii infection among childbearing age women in Kerman city, southeastern Iran. J Parasit Dis Off organ Indian Soc Parasitol. 2016;40(4):1544-7.

8. Tegegne $D$, Abdurahaman $M$, Yohannes $M$. Seroepidemiology and associated risk factors of Toxoplasma gondii in sheep and goats in Southwestern Ethiopia. BMC Vet Res. 2016;12(1):280.

9. Tonouhewa ABN, Akpo Y, Sessou P, Adoligbe C, Yessinou E, Hounmanou YG, et al. Toxoplasma gondii infection in meat animals from Africa: Systematic review and meta-analysis of seroepidemiological studies. Vet world. 2017;10(2):194.

10. Sarkari B, Asgari Q, Bagherian N, Esfahani SA, Kalantari M, Mohammadpour I, et al. Molecular and serological evaluation of toxoplasma gondii infection in reared turkeys in Fars Province, Iran. Jundishapur J Microbiol. 2014;7(7).

11. Rassouli M, Razmi GR, Bassami MR, Movassaghi AR, Azizzadeh M. Study on ovine abortion associated with Toxoplasma gondii in affected herds of Khorasan Razavi Province, Iran based on PCR detection of fetal brains and maternal serology. Parasitology. 2011;138(6):691-7.

12. Mahmoudvand $H$, Tavakoli kareshk $A$, moradi $M$, monzote fidalgo $L$ et al. Efficacy and Safety of Zataria multiflora Boiss Essential Oilagainst Acute Toxoplasmosis in Mice. Iran J Parasitol.2020;15(1),22-30.

13. Dubey JP, Rajendran C, Ferreira LR, Martins J, Kwok OCH, Hill DE, et al. High prevalence and genotypes of Toxoplasma gondii isolated from goats, from a retail meat store, destined for human consumption in the USA. Int J Parasitol. 2011;41(8):827-33.

14. Habibi GR, Imani AR, Gholami MR, Hablolvarid MH, Behroozikhah AM, Lotfi M, et al. Detection and identification of Toxoplasma gondii type one infection in sheep aborted fetuses in Qazvin Province of Iran. Iran J Parasitol. 2012;7(3):64.

15. Fazaeli A, Carter PE, Darde ML, Pennington TH. Molecular typing of Toxoplasma gondii strains by GRA6 gene sequence analysis. Int J Parasitol. 2000;30(5):637-42.

16. Guo M, Dubey JP, Hill D, Buchanan RL, Gamble HR, Jones JL, et al. Prevalence and risk factors for Toxoplasma gondii infection in meat animals and meat products destined for human consumption. J Food Prot. 2015;78(2):457-76. 
17. Tavakoli Kareshk A, Mahmoudvand H, Keyhani A, Oliaee TR, Mohammadi MA, Babaei Z, et al. Molecular detection and genetic diversity of Toxoplasma gondii in different tissues of sheep and goat in Eastern Iran. Trop Biomed. 2017;34:681_690.

18. Lopes AP, Dubey JP, Neto F, Rodrigues A, Martins T, Rodrigues M, et al. Seroprevalence of Toxoplasma gondii infection in cattle, sheep, goats and pigs from the North of Portugal for human consumption. Vet Parasitol. 2013;193(1-3):266-9.

19. Asgari Q, Sarkari B, Amerinia M, Panahi S, Mohammad-pour I, Sarvestani AS. Toxoplasma Infection in farm animals: a seroepidemiological survey in Fars province, south of Iran. Jundishapur $\mathrm{J}$ Microbiol. 2013;6(3):269.

20. Kamyabi H, Bahrieni M, Beigzadeh M, Harandi MF, Zia-Ali N. Risk Factors Analysis Associated with Seropositivity to Toxoplasma gondii in Sheep and Goats in Southeastern Iran Using Modified Agglutination Test (MAT). Iran J Parasitol. 2008;3:1-2.

21. Raeghi S, Akaberi A, Sedeghi S. Seroprevalence of Toxoplasma gondii in sheep, cattle and horses in Urmia North-West of Iran. Iran J Parasitol. 2011;6(4):90.

22. Sharif M, Gholami SH, Ziaei H, Daryani A, Laktarashi B, Ziapour SP, et al. Seroprevalence of Toxoplasma gondii in cattle, sheep and goats slaughtered for food in Mazandaran province, Iran, during 2005. Vet J. 2007;174(2):422-4.

23. Heidari H, Gharekhani J, Tavoosidana GR. Role of toxoplasmosis in abortion of ewes in western Iran: a serological study. Sci Parasitol. 2013;14(2):99-103.

24. Zhang N, Wang S, Wang D, Li C, Zhang Z, Yao Z, et al. Seroprevalence of Toxoplasma gondii infection and risk factors in domestic sheep in Henan province, central China. Parasite. 2016;23.

25. Yin M-Y, Wang J-L, Huang S-Y, Qin S-Y, Zhou D-H, Liu G-X, et al. Seroprevalence and risk factors of Toxoplasma gondii in Tibetan Sheep in Gansu province, Northwestern China. BMC Vet Res. 2015;11(1):41.

26. Tavakoli Kareshk A, Mahmoudvand H, Keyhani A, Oliaee TR, Mohammadi MA, Babaei Z, et al. Molecular detection and genetic diversity of Toxoplasma gondii in different tissues of sheep and goat in Eastern Iran. Trop Biomed. 2017;34:681-90.

27. Azizi $H$, Shiran B, Boroujeni AB, Jafari M. Molecular survey of Toxoplasma gondii in sheep, cattle and meat products in Chaharmahal va Bakhtiari Province, Southwest of Iran. Iran J Parasitol. 2014;9(3):429.

28. Amdouni Y, Rjeibi MR, Rouatbi M, Amairia S, Awadi S, Gharbi M. Molecular detection of Toxoplasma gondii infection in slaughtered ruminants (sheep, goats and cattle) in Northwest Tunisia. Meat Sci. 2017;133:180-4.

29. Taylor S, Barragan A, Su C, Fux B, Fentress SJ, Tang K, et al. A secreted serine-threonine kinase determines virulence in the eukaryotic pathogen Toxoplasma gondii. Science (80-). 2006;314(5806):1776-80.

30. da Silva IB, de Andrade Batista TP, Martines RB, Kanamura CT, Ferreira IMR, Vidal JE, et al. Genotyping of Toxoplasma gondii: DNA extraction from formalin-fixed paraffin-embedded autopsy 
tissues from AIDS patients who died by severe disseminated toxoplasmosis. Exp Parasitol. 2016;165:16-21.

31. Genot S, Franck J, Forel J-M, Rebaudet S, Ajzenberg D, de Paula AM, et al. Severe Toxoplasma gondii $\mathrm{I} / \mathrm{III}$ recombinant-genotype encephalitis in a human immunodeficiency virus patient. J Clin Microbiol. 2007;45(9):3138-40.

32. Khodaverdi M, Razmi G. Prevalence and genotyping of Toxoplasma gondii in stray cats in Mashhad area, Iran. BMC Vet Res. 2019;15(1):1-6.

33. Danehchin L, Razmi G, Naghibi A. Isolation and genotyping of Toxoplasma gondii strains in ovine aborted fetuses in Khorasan Razavi Province, Iran. Korean J Parasitol. 2016;54(1):15.

34. Armand B, Solhjoo K, Kordshooli MS, Davami MH, Pourahmad M, Orfaee V. Toxoplasma gondii Type I, predominant genotype isolated from sheep in South of Iran, Veterinary World, 10 (4): 386-392. In Abstract; 2017.

35. Zia-Ali N, Fazaeli A, Khoramizadeh M, Ajzenberg D, Dardé M, Keshavarz-Valian H. Isolation and molecular characterization of Toxoplasma gondii strains from different hosts in Iran. Parasitol Res. 2007;101(1):111-5.

36. Xu P, Li X, Tang F, Liu YH, Kou X, Zhao ML, et al. Research Note Seroprevalence and risk factors for Toxoplasma gondii in sheep and goats in Jinzhou, Northeastern China. Trop Biomed. 2015;32(3):563-7.

37. Gebremedhin EZ, Abdurahaman M, Hadush T, Tessema TS. Seroprevalence and risk factors of Toxoplasma gondii infection in sheep and goats slaughtered for human consumption in Central Ethiopia. BMC Res Notes. 2014;7(1):696.

\section{Figures}

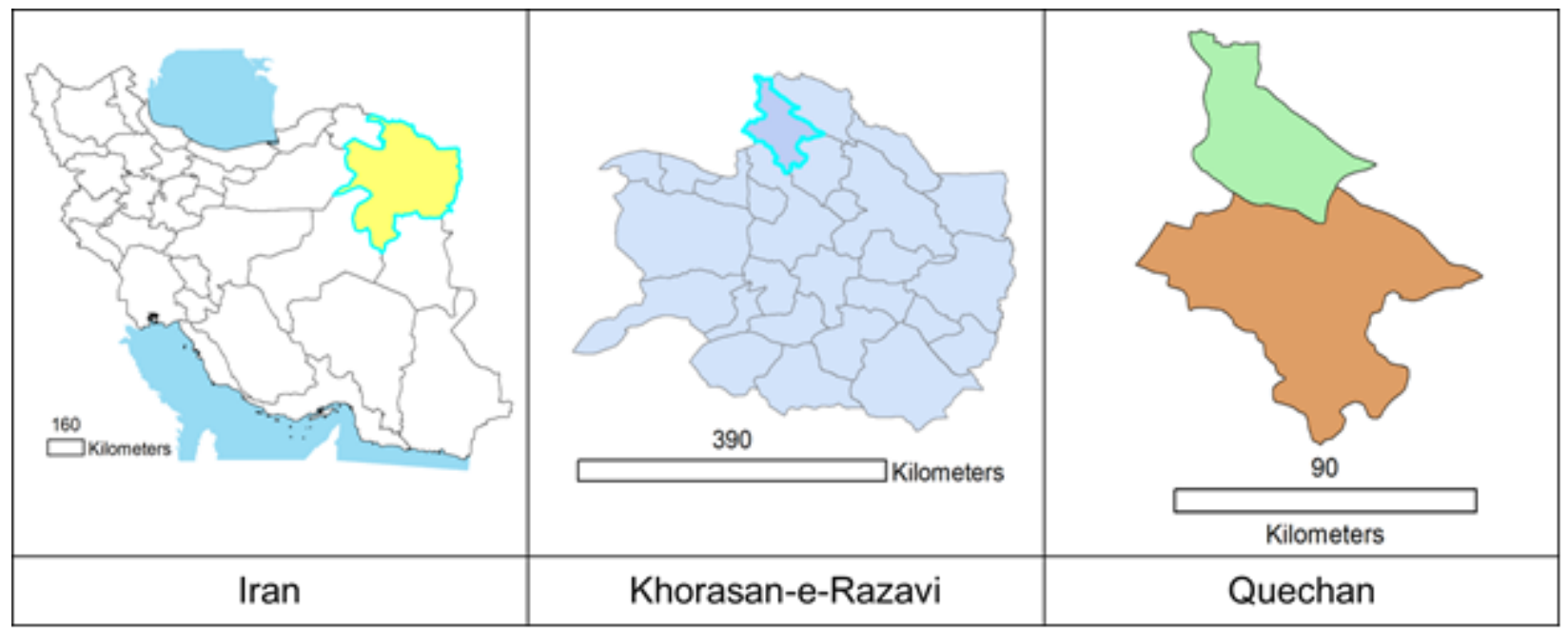

\section{Figure 1}

The situation of KhorasanRazavi Province in Iran and location of study area in Quechan. 


\section{Figure 2}

Electrophoretic pattern of the PCR products of B1 gene (531bp) from tissue samples. Lines 1-6: diaphragm tissue of sheep, lanes 7-11: heart tissues of sheep, lanes 12-16: diaphragm tissues of goats, lanes 17\&18: heart tissues of goats, lane 18: positive control, lane 19: negative control, lane M: DNA marker

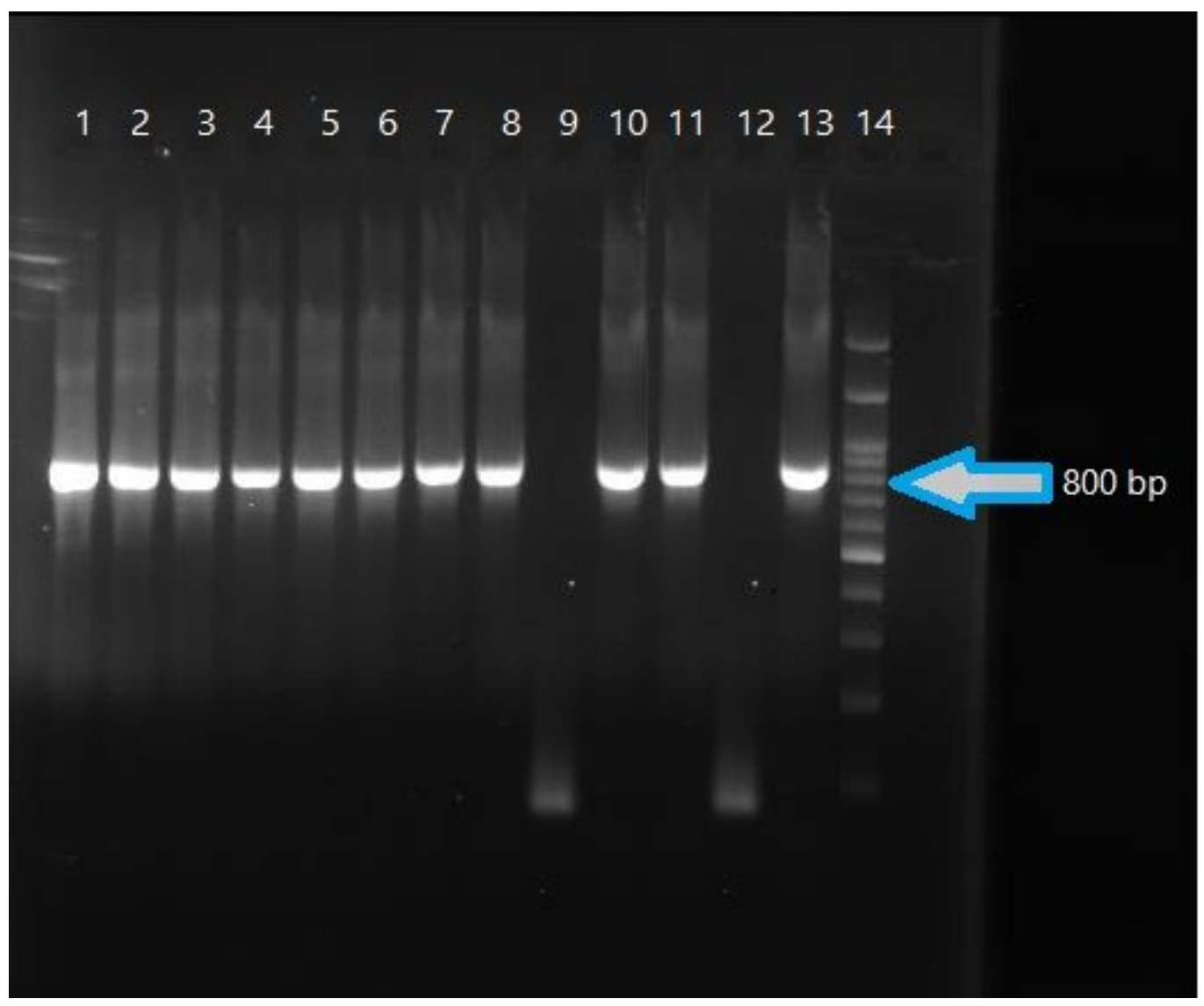

\section{Figure 3}

Electrophoretic pattern of the PCR products of GRA6 gene from tissue samples. Lanes 1-6: diaphragm tissue of sheep, lane 7: heart tissues of sheep, lanes 8-11: diaphragm tissues of goats, lane 12: negative 


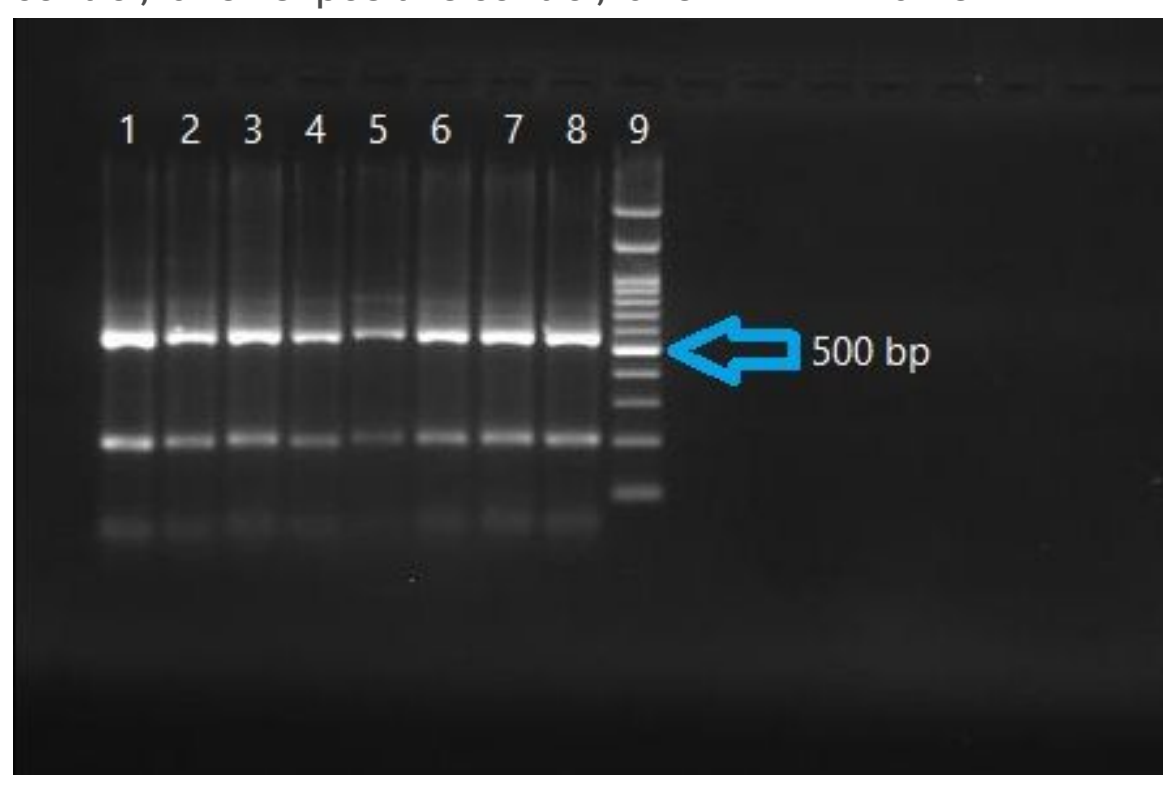

\section{Figure 4}

PCR-RFLP analysis of GRA6 gene coding region with Msel endonuclease. Lane 9 is DNA marker, Lanes 18 are Toxoplasma gondii, type I $(\mathrm{RH})$. 

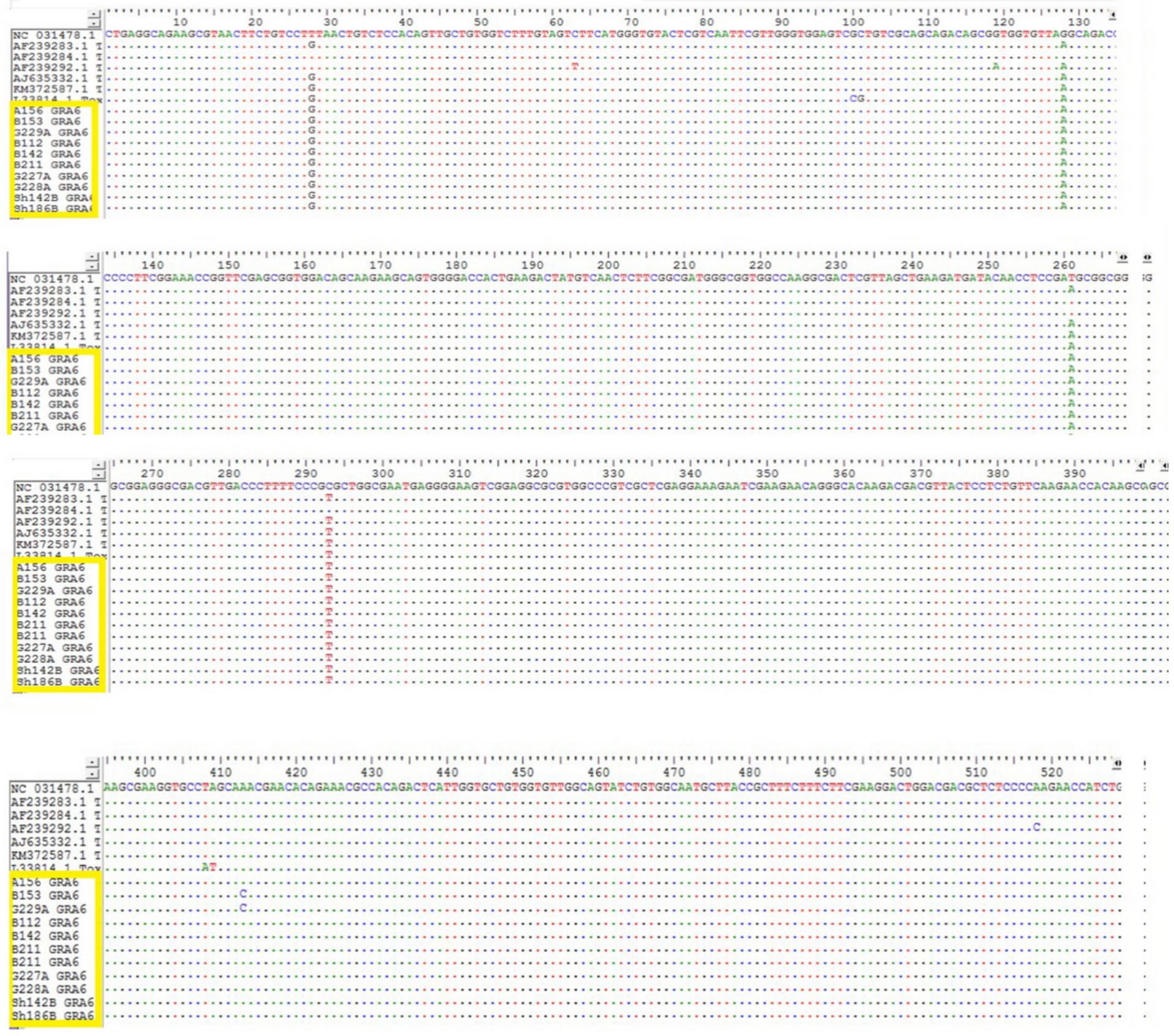

\section{Figure 5}

The comparison of sequencing of GRA6 gene isolated from sheepand goats with gene bank sequences 


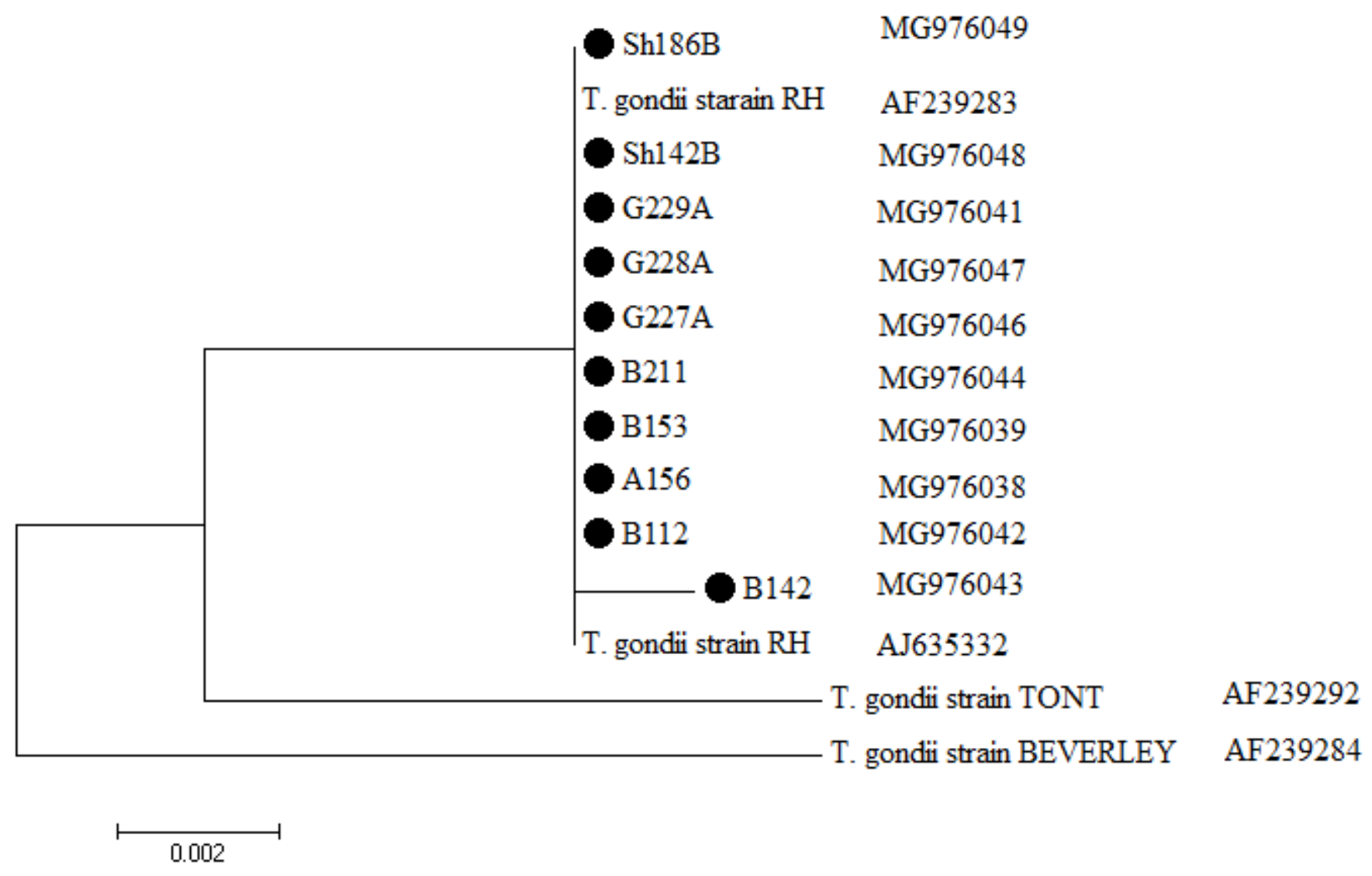

Figure 6

The phylogenic tree was constructed by maximum likelihood method using the nucleotide sequence of reference strains and our isolates (indicated with colorful shapes behind them). The scale bar indicates a $2 \%$ nucleotide difference

\section{Supplementary Files}

This is a list of supplementary files associated with this preprint. Click to download.

- graphicalabstract.png 